\author{
KS. JÓZEF WROCEŃSKI SCJ \\ Wydział Prawa Kanonicznego \\ Uniwersytetu Kardynała Stefana Wyszyńskiego w Warszawie \\ ORCID 0000-0003-4817-9196
}

\title{
BISKUPI TYTULARNI W PRAWIE KOŚCIOŁA ŁACIŃSKIEGO
}

Treść: Wstęp. - 1. Geneza instytucji biskupa tytularnego. - 2. Biskupi tytularni w postanowieniach Kodeksu Prawa Kanonicznego z 1917 roku. 2.1. Biskupi koadiutorzy i pomocniczy. - 2.2. Inne urzędy spełniane przez biskupów tytularnych. - 3. Wpływ II Soboru Watykańskiego na zmianę pozycji prawnej biskupów tytularnych. - 4. Postanowienia II Soboru Watykańskiego i ustawodawstwa posoborowego dotyczące biskupów koadiutorów i pomocniczych. - 5. Biskupi tytularni w świetle Kodeksu Jana Pawła II i dokumentów pokodeksowych. - Zakończenie.

\section{Wstęp}

Biskupi jako następcy Apostołów od początku istnienia Kościoła pełnią w nim pierwszorzędna rolę będąc członkami Kolegium Biskupów i pasterzami Kościołów partykularnych. Do VII wieku, czyli do pojawienia się islamu, w każdym Kościele partykularnym był jeden biskup, który nim kierował. W wieku VII i VIII na skutek inwazji muzułmanów na kraje chrześcijańskiego Wschodu, Afryki Północnej i Hiszpanii wielu biskupów tamtejszych diecezji musiało opuścić swoje stolice biskupie ${ }^{1}$. Chroniąc się przed prześladowaniami przenosili się do innych krajów chrześcijańskich, zwłaszcza europejskich,

${ }^{1}$ Por. F. Bączkowicz, Prawo Kanoniczne. Podręcznik dla duchowieństwa, t. I, Opole 1957, s. 519. 
w których stolice biskupie były obsadzone. Początkowo uważano, że biskupi ci nie utracili opuszczonych stolic, a jedynie możność aktualnego sprawowania jurysdykcji. Nie byli jednak uważani za pełnoprawnych pasterzy diecezji w nowym miejscu pobytu. Po ich śmierci udzielano sakry biskupiej nowym kandydatom, przeznaczonym do tych opuszczonych diecezji z myślą, że będą mogli tam powrócić ${ }^{2}$, zwłaszcza w kontekście organizowanych wypraw krzyżowych ${ }^{3}$. Najczęściej jed nak biskupi ci nie powracali do opuszczonych stolic, zatrzymując jedynie ich tytuły. Pełnili, więc oni funkcje pomocnicze, służąc pomocą biskupom rezydencjalnym, zwłaszcza w wypełnianiu obowiązków wynikających z sakry biskupiej. Z biegiem czasu wytworzył się zwyczaj mianowania biskupów nierezydencjalnych z tytułami diecezji aktualnie nieistniejących, którzy pomagali w pracy pasterskiej biskupom diecezjalnym. Przez długi jednak czas status prawny tych biskupów był niedookreślony pod względem prawnym. Ich pozycja uległa dowartościowaniu, szczególnie w kontekście dokumentów II Soboru Watykańskiego. W podstawowym dokumencie tegoż Soboru, konstytucji dogmatycznej o Kościele Lumen gentium ${ }^{4}$ znalazło się obszerne naświetlenie pozycji biskupa we wspólnocie kościelnej. Ponadto odrębny dokument, dekret Christus Dominus ${ }^{5}$ został poświęcony pasterskim zadaniom biskupów w Kościele. Stanowisko Soboru zostało potwierdzone w dokumentach prawodawstwa posoborowego ${ }^{6}$, a szczególnie

2 Por. W. Góralski, Biskup tytularny, w: Encyklopedia Katolicka, t. II, Lublin 1985, kol. 614-615.

${ }^{3}$ Por. M. Banaszak, Historia Kościoła katolickiego, t. II, Warszawa 2009, s. 127$128 ; 150-156$.

${ }^{4}$ Sobór Watykański II, Konstytucja dogmatyczna o Kościele Lumen gentium, w: Sobór Watykański II, Konstytucje Dekrety Deklaracje, Pallottinum 2002, s. 104-166.

${ }^{5}$ Sobór Watykański II, Dekret o pasterskich zadaniach biskupów w Kościele Christus Dominus, w: Sobór Watykański II, Konstytucje Dekrety Deklaracje, Pallottinum 2002, s. 236-258.

${ }^{6}$ Por. Paulus VI, Motu proprio Ecclesiae Sanctae, AAS 57(1966) 757-787. 
w Kodeksie Jana Pawła II ${ }^{7}$. W związku z powyższym wydaje się ciekawy problem badawczy zawarty w pytaniu jak na przestrzeni wieków kształtowała się pozycja prawna biskupa tytularnego w Kościele i jaki jest jej kształt obecnie?

\section{Geneza instytucji biskupa tytularnego}

Jak wspomniano wyżej zasadniczy wpływ na kształtowanie się instytucji biskupa tytularnego miały wydarzenia historyczne wczesnego średniowiecza. Gdy w wieku VII i VIII kraje katolickiego Wschodu, Afryki Północnej i Hiszpanii zostały zdobyte przez muzułmanów. Na skutek prześladowań tereny te były masowo opuszczane przez chrześcijan ${ }^{8}$. Edykty prześladowcze były tak drastyczne, że aby zachować życie i wierność religii, chrześcijanie w tym także biskupi przenosili się do Europy. Z kolei z przejściem na islam wiązało się zwolnienie od podatków, a nawet wolność osobista. Ci biskupi przybysze byli nazywani episcopi in partibus infidelium, co miało swoje uzasadnienie w tym, że terytoria, na których leżały ich diecezje były rzeczywiście w rękach niewiernych, głównie muzułmanów ${ }^{9}$. Byli oni początkowo chętnie przyjmowani przez biskupów w Europie z powodu rozległości niektórych diecezji i wynikających stąd obowiązków pasterskich, którym nie zawsze mogli podołać miejscowi biskupi, często pełniący też role polityczne ${ }^{10}$. Zadania, jakie otrzymywali biskupi przybysze

${ }^{7}$ Codex Iuris Canonici auctoritate Joannis Pauli PP. promulgatus. Kodeks Prawa Kanonicznego. Przekład polski zatwierdzony przez Konferencję Episkopatu, Pallottinum 1984 (dalej KPK/83).

${ }^{8}$ Liczba biskupstw na tych terenach zmniejszała się gwałtownie. W wieku X istniały jeszcze 4 prowincje kościelne i ok. 40 diecezji. W połowie XI wieku było ich tylko 5, a nawet 3. Stare biskupstwo Kartaginy, pochodzące z II wieku, po raz ostatni figuruje w wykazie w 1192 roku (por. B. Kumor, Historia Kościoła, t. II, Lublin 1973, s. 48).

${ }_{9}$ Por. A. Sotkiewicz, Biskup in partibus infidelium, w: Encyklopedia Kościelna, t. II, Warszawa 1873, s. 373; E. SzTAfrowski, Biskupi koadiutorzy i pomocniczy, Prawo Kanoniczne 22(1979) nr 3-4, s. 58.

10 Zdarzały się przypadki, że nawet papieże mianowali tymczasowo biskupów przybyszów na wakujące diecezje, np. pap. Grzegorz Wielki (1073-1085) w Italii lub jako pomocników w zarządzie diecezją, np. pap. Benedykt IX (1032-1044) dla 
w nowych diecezjach, to przede wszystkim pomaganie miejscowym biskupom, udzielanie święceń i sakramentu bierzmowania, odprawianie nabożeństw. Wszystkie swoje funkcje mogli spełniać tylko na wyraźne polecenie lub życzenie miejscowego biskupa ${ }^{11}$.

Pomoc, którą biskupi ci świadczyli miejscowym pasterzom z czasem okazała się pożyteczna, a nawet niezbędna. Dlatego po ich śmierci konsekrowano innych z tymi samymi tytułami stolic biskupich i z nadzieją, że tereny zabrane zostaną odbite i zostanie tam przywrócona dawna administracja kościelna. Warunkiem jednak nominacji była stała pomoc pasterzom diecezji, do których byli przydzieleni. Należy zaznaczyć, że sytuacja ta nie była zgodna $\mathrm{z}$ wielowiekową tradycją Kościoła. Bowiem już pierwszy Sobór w Nicei w 325 roku stanowił, aby w diecezji był tylko jeden biskup i aby nie wykonywał on jurysdykcji w innym Kościele ${ }^{12}$. Dlatego dodatkowi biskupi nie byli przez wszystkich biskupów chętnie przyjmowani. Sprzeciwiał się im także pap. Aleksander III (1159-1181). Podobną uchwałę podjął Sobór Laterański III w 1179 roku $^{13}$. Wprowadzenie jednak tej uchwały w życie napotkało sprzeciw ze strony biskupów in partibus infidelium. Do ich protestu przyłączyli się niektórzy biskupi diecezji. W związku z tym pap. Klemens V (1305-1314) na Soborze w Vienne w 1311 roku wydał dekret na mocy którego zabronił mianowania biskupów dla Kościołów wschodnich, niemających obecnie wiernych i własnego duchowieństwa bez zgody Stolicy Apostolskiej ${ }^{14}$.

Mimo organizowanych wypraw krzyżowych na stałe nie odzyskano utraconych terenów, a biskupi stolic utraconych byli nadal

arcybiskupa w Rewirze (por. J. Hergenrother, Historia powszechna Kościoła katolickiego, t. V, Warszawa 1901, s. 115).

${ }^{11}$ Por. F. BĄczkowicz, Prawo Kanoniczne. Podręcznik..., s. 520.

${ }^{12}$ Por. Sobór Nicejski I, Kan. XV i XVI, w: Dokumenty Soborów Powszechnych, opr. A. Baron. H. Pietras, t. I, Kraków 2003, s. 41-42.

${ }^{13}$ Por. Conciliorum Oecumenicorum Decreta, Bologna 1973, s. 540; Sobór Laterański III, Kan. XIII i XIV, w: Dokumenty Soborów Powszechnych, opr. A. Baron. H. Pietras, t. II, Kraków 2003, s. 187-189.

${ }^{14}$ Por. Tamże, s. 555; Sobór w Vienne, Dekret 7, w: Dokumenty Soborów Powszechnych, opr. A. Baron. H. Pietras, t. II, Kraków 2003, s. 541-545. 
mimo zakazów przydzielani do biskupstw europejskich, co powoli stawało się zwyczajem. W związku z tym Sobory w Konstancji (1414-1418) i w Bazylei (1431-1445) chcąc dowartościować tych biskupów dopuściły ich do obrad soborowych, powołując się na Apostołów, którzy początkowo także nie posiadali określonych Kościołów ${ }^{15}$. W związku z tym powoli wzrastała liczba biskupów tytularnych. W niektórych okresach historii Kościoła ich liczba była bardzo pokaźna. Zdarzało się nawet, że biskupi rezydencjalni nie przyjmowali sakry biskupiej, a w swych obowiązkach wyręczali się biskupami tytularnymi. Niezależnie od tego nawet ci biskupi ordynariusze, którzy mieli sakrę biskupią bardzo często potrzebowali pomocy biskupów tytularnych, ponieważ sami przebywali nieraz z dala od diecezji ${ }^{16}$. Taka sytuacja w praktyce prowadziła do nadużyć ze strony biskupów niemających swoich diecezji. Wydawali oni niekiedy dokumenty ze szkodą dla diecezji, święcili osoby nienadające się do stanu duchownego. Przeciw tym nadużyciom wystąpił Sobór Trydencki (1545-1563) powołując się na stare rozporządzenie zabraniające biskupom pełnienia funkcji w diecezji innego biskupa bez jego zgody ${ }^{17}$. Tenże Sobór pozostawił dotychczasową ich nazwę: episcopi in partibus infidelium, która przetrwała do drugiej połowy XIX wieku. Powodem takiej sytuacji był fakt, że w Kościele ciągle liczono się z tym, że utracone tereny w Afryce i Azji zostaną kiedyś odzyskane. Dlatego też Stolica Apostolska nadal mianowała biskupów na utracone stolice biskupie, mimo iż nie mogli oni wykonywać w nich żadnej władzy i kierowano

\footnotetext{
${ }^{15}$ Por. Tamże, s. 570; Sobór w Konstancji, Sesja I, w: Dokumenty Soborów Powszechnych, opr. A. Baron. H. Pietras, t. III, Kraków 2004, s. 35; Sobór w Bazylei, Sesja III, w: Dokumenty Soborów Powszechnych, opr. A. Baron. H. Pietras, t. III, Kraków 2004, s. 289.

${ }^{16}$ Por. E. Sztafrowski, Współpracownicy biskupa diecezjalnego w pasterskim postugiwaniu, Warszawa 1977, s. 21.

${ }^{17}$ Por. Sobór Trydencki, Sesja VI, II. Dekret o rezydowaniu biskupów, rozdz. I i V, w: Dokumenty Soborów Powszechnych, opr. A. Baron. H. Pietras, t. IV, Kraków 2005, s. 319-323 i s. 325.
} 
ich do pomocniczej pracy biskupiej ${ }^{18}$. Czyniono też tak, dlatego, aby uniknąć nadużyć polegających na udzielaniu sakry biskupiej bez żadnego określonego tytułu. Nazwa biskup sufragan, która z prawa przysługuje biskupom diecezji podporządkowanym metropolicie była często przez tych biskupów uzurpowana ${ }^{19}$.

$\mathrm{Z}$ biegiem lat coraz bardziej okazywało się, że nadzieje na odzyskanie utraconych diecezji są nikłe zarówno z powodów militarnych jak i politycznych. Na tych terenach nie było też już chrześcijan, albo byli w znikomej liczbie. Mianowanie, więc biskupów na utracone stolice było zbyteczne. Jednak ze względu na pomoc, jaką świadczyli biskupom diecezji, a także w Kurii Rzymskiej lub jako nuncjusze papiescy czy wikariusze apostolscy ich nominacje były nadal pożądane. $\mathrm{Z}$ tą kwestią wiązał się również problem ich godności, bowiem chociaż nie była im powierzana żadna wspólnota wiernych, to jednak posiadali ważne święcenia biskupie. W tym kontekście rodziło się pytanie, czy mogą cieszyć się tymi samymi prawami, co biskupi rezydencjalni. Sprawa ta, dyskutowana wcześniej, odżyła w związku z zapowiedzią pap. Piusa IX zwołania Soboru Watykańskiego I i uczestnictwa w nim biskupów tytularnych z prawem głosu decydującego. Znaczna część ówczesnych teologów opowiadała się za przyznaniem im takiego prawa. Uważali oni, że prawo takie ma swoją podstawę w powszechnej jurysdykcji, którą posiadają na mocy konsekracji ${ }^{20}$. Papież Pius IX w Bulli Aeterni Patris z dnia 29 czerwca 1868 r. zwołującej Sobór Watykański I, dopuścił biskupów tytularnych do udziału w Soborze z prawem głosu decydującego ${ }^{21}$. Problem statusu biskupów tytularnych podjął także, następca Piusa IX, pap. Leon XIII, który na mocy

\footnotetext{
${ }^{18}$ Por. T. Pawluk, Prawo kanoniczne według Kodeksu Jana Pawła II, t. II, Olsztyn 1985, s. 174.

${ }_{19}$ Por. P. Paschini, Vescovo, w: Enciclopedia Cattolica, t. XII, Citta del Vaticano 1954, kol. 1317.

${ }^{20}$ Por. E. Sztafrowski, Kolegialność hierarchii kościelnej przed Soborem Watykańskim II, Prawo Kanoniczne 16(1973) nr 1-2, s. 38.

${ }^{21}$ Por. Pius IX, Litt.ap. Aeterni Patris 29 iun. 1868, ASS 4(1868), s. 3-9. Szerzej na ten temat por. H. BogACKI, Teoria soboru powszechnego w przygotowaniu i obradach I Soboru Watykańskiego, Warszawa 1965, s. $171 \mathrm{nn}$.
} 
Bulli In suprema z dnia 10 czerwca 1882 r. zmieniał nazwę: episcopus in partibus infidelium na nową: episcpous titularis ${ }^{22}$. W tym samym roku, 8 listopada 1882 r. Kongregacja Rozkrzewiania Wiary nakazała, także biskupom tytularnym sprawowanie Mszy św. pro populo $\mathrm{w}$ dni świąteczne ${ }^{23}$. Chociaż zniesiono określenie biskup in partibus infidelium, to jednak pozostawiono sam zwyczaj przydzielania tym biskupom siedzib już nieistniejących diecezji. Należy też podkreślić, że nazwa biskup tytularny stanowiła termin ogólny używany na oznaczenie wszystkich, którzy otrzymywali sakrę biskupią, ale nie byli mianowani pasterzami określonego Kościoła partykularnego ${ }^{24}$.

\section{Biskupi tytularni w postanowieniach Kodeksu Prawa Kanonicznego z 1917 roku}

Proces industrializacji, który rozpoczął się w połowie XIX wieku powodował gwałtowny wzrost liczebności wiernych w wielu diecezjach zwłaszcza miejskich i miał wpływ na pozycję biskupów tytularnych. Stawali się oni coraz bardziej pożyteczni i potrzebni wspierając, biskupów diecezji w ciągle wzrastających obowiązkach pasterskich. Stąd też prawodawca kościelny nie mógł ich pominąć w pierwszym Kodeksie Prawa Kanonicznego ${ }^{25}$. I chociaż bezpośrednio o biskupach tytularnych mówił niewiele, to jednak wspominał o nich także w przepisach dotyczących urzędów biskupa koadiutora i biskupa pomocniczego.

$Z$ racji pełnionych zadań w Kościele powszechnym prawodawca podzielił biskupów na rezydencjalnych i tytularnych. Rezydencjalnymi,

${ }^{22}$ Por. Leo XIII Litt. Ap. In suprema 10 iun. 1882, w: Codicis Iuris Canonici Fontes, P. Gasparri, vol. III, Typis Polyglottis Vaticanis 1933, s. 193-198.

${ }^{23}$ Por. Sacra Congregatio de Propaganda Fide, Litt. Encycl (ad Deleg. Ap. Pro Oriente) 8 nov. 19882, w: Codicis Iuris Canonici Fontes, I. Seredi, vol. VII, Typis Polyglottis Vaticanis 1935, s. 273-274.

24 Por. E. Sztafrowski, Biskupi koadiutorzy..., s. 58-59.

${ }^{25}$ O biskupach tytularnych była mowa w Księdze II zatytułowanej De personis, w części I De clericis, szczególnie w kan. 329-355. Por. Codex Iuris Canonici Pii X Pontificis Maximi iussu digestus Benedicti Papae XV auctoritate promulgatus, Typis Polyglottis Vaticanis 1936 (dalej KPK/1917). 
czyli diecezjalnymi nazywał tych, którzy byli zwyczajnymi i bezpośrednimi pasterzami w powierzonych sobie diecezjach ${ }^{26}$. Tytularnych zaś określał jako tych, którzy nie mieli żadnej władzy w diecezji, której nie posiadali ${ }^{27}$.

Prawodawca poprzedniego Kodeksu określił jasno pozycję i zadania, jakie stawiał wszystkim biskupom. Mimo to widać wyraźnie akcentowanie na pierwszym miejscu aspektu jurysdykcyjnego, co jest właśnie czymś charakterystycznym dla kodeksowej doktryny na temat biskupów. Jak wiadomo już w kan. 329 nazywał biskupów następcami Apostołów, którzy z Bożego ustanowienia przewodzą poszczególnym Kościołom, którymi rządzą zwyczajną władzą pod przewodnictwem Biskupa Rzymskiego ${ }^{28}$. Wydaje się, że w tej definicji uwidocznione zostało wyraźne podkreślenie następstwa apostolskiego, które przysługuje wszystkim biskupom, a co za tym idzie, zobowiązuje ich by troszczyli się razem z Papieżem o cały Kościół, sprawując swą biskupią władzę w powierzonych im diecezjach. Uwzględniając jednak kontekst, należy zauważyć, że to następstwo apostolskie odnoszone jest, praktycznie rzecz biorąc, do biskupów rezydencjalnych. Owszem wydaje się, że termin biskupi odnosi Kodeks tylko do tych, którzy zarządzają diecezja $\mathrm{mi}^{29}$. W ten sposób termin biskup stał się właściwie terminem technicznym na oznaczenie biskupa rezydencjalnego, a nawet tych rządców diecezji, którzy są przyrównani biskupom rezydencjalnym, chociaż nie posiadają sakry biskupiej ${ }^{30}$. Ponadto prawodawca kodeksowy w tych kanonach, które poświęcił biskupom tytularnym nie powtórzył, że i oni są następcami Apostołów, ograniczając się do negatywnego stwierdzenia, iż nie mogą wykonywać żadnej władzy w swoich tytularnych tylko diecezjach. Mimo to jednak podkreślał ich troskę o cały Kościół. I tak w kan. $348 \$ 1$ wyraźnie stwierdzał, że

\footnotetext{
26 Por. KPK/1917, kan. $334 \$ 1$.

27 Por. Tamże, kan. 348.

${ }^{28}$ Por. Tamże, kan. $329 \$ 1$.

${ }^{29}$ Potwierdzenie tego stanu rzeczy można znaleźć zwłaszcza w kan. 350-355.

${ }^{30}$ Por. E. Sztafrowski, Kolegialność biskupów według Konstytucji soborowej „Lumen gentium”, Prawo Kanoniczne 15(1972) nr 3-4, s. 7.
} 
chociaż biskupi tytularni nie maja żadnej władzy w diecezji, której realnie nie posiadają, to jednak zachęcał, aby z miłości czasem odprawiali Mszę św. za swoją diecezję, podkreślając w ten sposób ich troskę o swoje tytularne diecezje ${ }^{31}$. Ta troska o Kościół powszechny miała się także przejawiać w wezwaniu biskupów tytularnych do udziału w Soborze ${ }^{32}$, synodzie plenarnym ${ }^{33}$ i prowincjalnym ${ }^{34}$. Wydaje się, że tenże prawodawca kodeksowy w tym względzie nie czynił żadnego rozróżnienia pomiędzy biskupami, chociaż wiadomo było, że biskupi tytularni nie posiadali swoich diecezji, w których by mogli samodzielnie sprawować swą władzę.

Mimo powyższych stwierdzeń należy zauważyć, że prawodawca Kodeksu z 1917 r. określając normy dotyczące ustanawiania biskupów stawiał wszystkim biskupom, zarówno rezydencjalnym jak i tytularnym te same wymogi. Najpierw stanowił, że zanim ktoś zostanie promowany na biskupa, należy stwierdzić według sposobu określonego przez Stolicę Apostolską czy jest do tego zdatny ${ }^{35}$, następnie jasno i wyraźnie określił wymogi stawiane kandydatom do urzędu biskupa $^{36}$. Ponadto biskupom tytularnym, podobnie jak biskupom re-

${ }^{31}$ Por. Tamże, kan, $348 \$ 2$.

${ }^{32}$ Por. Tamże, kan. $223 \$ 2$. Wśród komentatorów poprzedniego Kodeksu nie było jednak zgodności w kwestii, czy biskupi tytularni musieli, czy tylko mogli być wezwani na Sobór, ponieważ prawodawca wyraźnie tego nie określił. Wskazał tylko, że biskupi tytularni wezwani na Sobór winni mieć głos decydujący, chyba, że w wezwaniu, co innego wyraźnie zastrzeżono.

${ }^{33}$ Por. Tamże, kan. $282 \S 2$. Jeśli chodzi o udział biskupów tytularnych w synodzie plenarnym, to mogli oni być powołani przez legata papieskiego z głosem decydującym, chyba, że w wezwaniu na synod zostało co innego postanowione.

${ }^{34}$ Por. Tamże, kan. $286 \$ 2$. Podobnie biskupi tytularni zamieszkujący terytorium prowincji mogli uczestniczyć w synodzie prowincjalnym z głosem decydującym, jeśli zostali wezwani przez przewodniczącego za zgodą większości uczestników synodu, którym przysługiwał głos decydujący i jeśli w wezwaniu nie zostało co innego postanowione.

35 Por. Tamże, kan. 330.

${ }^{36}$ Por. Tamże, kan. $331 \S 1$. Kandydat miał cieszyć się: prawym pochodzeniem, mieć ukończony trzydziesty rok życia, przynajmniej pięć lat kapłaństwa, odznaczać się dobrymi obyczajami (pobożnością, gorliwością, roztropnością oraz innymi 
zydencjalnym, przysługiwało szereg praw i przywilejów ${ }^{37}$ dotyczących noszenia stroju i insygniów biskupich, sprawowania sakramentów i sakramentaliów, rozgrzeszania z cenzur kościelnych, przepowiadania Słowa Bożego, erygowania kaplic domowych. Udzielono im też szereg przywilejów honorowych ${ }^{38}$.

\subsection{Biskupi koadiutorzy i pomocniczy}

Prawodawca poprzedniego Kodeksu omawiając urzędy zajmowowane przez biskupów tytularnych, wymieniał wśród nich urząd biskupa koadiutora i biskupa pomocniczego. Na określenie tych urzędów używał terminów; episcopus coadiutor i episcopus auxiliaris. Terminy te posiadały prawie identyczny źródłosłów i znaczyły wspomaganie kogoś, udzielanie komuś pomocy. Koadiutorem nazywano biskupa, który podejmował zadania kierowania diecezją w sytuacji niemożności spełniania swych obowiązków przez biskupa rezydencjalnego. Ta niemożność mogła wynikać z różnych powodów, stąd prawodawca kodeksowy wyróżniał wśród biskupów koadiutorów: koadiutora danego osobie biskupa (c. personae episcopi datus) ${ }^{39} \mathrm{i}$ koadiutora danego diecezji (c. sedi datus ${ }^{40}$ i stanowił, że koadiutora zwykło się dawać osobie biskupa z prawem następstwa, niekiedy jednak dawany był także stolicy ${ }^{41}$. W razie wakatu stolicy biskupiej koadiutor z prawem następstwa zostawał od razu ordynariuszem diecezji, w której był ustanowiony, byleby wcześniej objął swój urząd

przymiotami potrzebnymi do rządzenia diecezją) ponadto doktorat lub przynajmniej licencjat $\mathrm{z}$ teologii lub z prawa kanonicznego, zdobyty w uniwersytecie czy instytucie naukowym, zatwierdzonym przez Stolicę Apostolską lub przynajmniej biegłość w zakresie tych nauk.

${ }^{37}$ Por. Tamże, kan. $349 \$ 1$.

38 Por. F. Bączkowicz, Prawo Kanoniczne. Podręcznik..., s. 519.

39 W tym przypadku koadiutor był ustanawiany, gdy biskup rezydencjalny był w podeszłym wieku, albo choroba bądź inna przeszkoda (np. internowanie, zesłanie, uwięzienie) nie pozwalały na samodzielne rządzenie diecezją

${ }^{40} \mathrm{~W}$ tej sytuacji koadiutor był przydzielany zazwyczaj ze względu na rozległość diecezji, której biskup rezydencjalny pasterzował.

${ }^{41}$ Por. KPK/17, kan. $350 \$ 2$. 
przez okazanie pisma nominacyjnego swemu biskupowi i kapitule katedralnej ${ }^{42}$.

Koadiutor dany osobie biskupa był mianowany i przydzielany przez papieża, który tez powiadamiał nominata w bulli nominacyjnej o jego prawach i obowiązkach, mocą, której został przydzielony do pomocy pasterzowi diecezji ${ }^{43}$. Jeśliby został przydzielony biskupowi zupełnie niezdolnemu do pełnienia swoich funkcji posiadał wówczas wszystkie prawa i obowiązki biskupa, dla którego został dany. Koadiutor dany osobie biskupa był, więc jakby zrównany z biskupem rezydencjalnym. Dany biskupowi zdolnemu do pełnienia swoich funkcji mógł spełniać tylko zajęcia zlecone przez biskupa. Jemu także, a nie innym biskup rezydencjalny powinien zlecać na stałe to, co może wykonywać. Winien także, gdy prosił go biskup, używać pontyfikaliów i spełniać inne czynności, do których sam biskup był zobowiązany ${ }^{44}$. Ponadto koadiutor posiadał prawo do godziwego utrzymania ${ }^{45}$. Należy zauważyć, że urząd koadiutora danego osobie biskupa był trwalszy i stwarzał większe możliwości udziału we władzy biskupa i większe szanse objęcia pełnych rządów w diecezji.

Z kolei koadiutor dany diecezji był także mianowany i przydzielany przez papieża, który też powiadamiał nominata w bulli nominacyjnej o jego prawach i obowiązkach względem diecezji, dla której był ustanawiany ${ }^{46}$. Podobnie jak koadiutor dany osobie biskupa urząd swój obejmował zgodnie z wymogami kanonów. Biskup koadiutor

${ }^{42}$ Por. Tamże, kan. $355 \$ 1$. Prawodawca kodeksowy żądał także, aby przedstawienie nominacji odbyło się zgodnie z wymogami prawa, tzn. aby obok kapituły kościoła katedralnego pismo apostolskie było okazane także w obecności sekretarza kapituły lub kanclerza kurii, który powinien sporządzić protokół (por. KPK/17, kan. $334 \S 3$.

${ }^{43}$ Por. Tamże, kan. $351 \$ 1$.

${ }^{44}$ Por. Tamże, kan. 351.

${ }^{45} \mathrm{Na}$ ogół prawo do utrzymania koadiutorowi zapewniał list prowizyjny. W przeciwnym wypadku musiałby go utrzymywać biskup (por. M. Coronata, Institutiones Iuris Canonici, vol I, Roma 1950, s. 480).

${ }^{46}$ Prawa i obowiązki, jakie przysługiwały biskupowi kaodaiutorowi od momentu wejścia w posiadanie urzędu, oprócz zawartych w piśmie apostolskim, to możliwość sprawowania wszystkich czynności biskupich (z wyjątkiem udzielania wyższych 
urząd swój sprawował zawsze pod zwierzchnictwem biskupa diecezji. W sytuacji, kiedy stolica biskupia zawakowała koadiutor nie tracił swego urzędu ${ }^{47}$. Jeśli był zamianowany z prawem następstwa stawał się ordynariuszem diecezji. Należy podkreślić, że prawo następstwa posiadał rzadziej, niż koadiutor dany osobie biskupa.

Trzecim urzędem spełnianym przez biskupów tytularnych był urząd biskupa pomocniczego (episcopus auxiliaris), czyli koadiutora danego osobie biskupa bez prawa następstwa ${ }^{48}$. On również był mianowany przez papieża, jednak przy objęciu urzędu wystarczyło, aby pismo nominacyjne okazał tylko biskupowi ${ }^{49}$. Zadania, jakie mógł spełniać w diecezji, były uzależnione wyłącznie od decyzji biskupa rezydencjalnego, chyba, że Stolica Apostolska co innego postanowiła w bulli nominacyjnej ${ }^{50}$. Biskup rezydencjalny mógł zawsze wezwać go, by sprawował za niego czynności pontyfikalne, których nie mógł spełnić osobiście ze względu na przeszkodę lub z powodu słusznej przyczyny ${ }^{51}$. Ponadto każdego koadiutora prawodawca zobowiązywał do przebywania na stałe w diecezji, wyjąwszy okres wakacji, bądź krótki okres nieobecności, jednak za zezwoleniem biskupa rezydencjalnego ${ }^{52}$. Można więc powiedzieć, że prawa i obowiązki, jakie przysługiwały biskupowi pomocniczemu były te same, jak w przypadku biskupów koadiutorów, wyjąwszy oczy wiście te, które wprost i bezpośrednio były związane z urzędem biskupa koadiutora. Urząd

święceń) oraz dokonywania tego, co zlecił mu biskup rezydencjalny (por. KPK/17, kan. 352).

${ }^{47}$ Por. Tamże, kan. $355 \$ 3$.

${ }^{48}$ Por. Tamże, kan. $350 \$ 3$. Zazwyczaj papież mianował biskupa pomocniczego do pomocy biskupowi rezydencjalnemu w spełnianiu czynności pontyfikalnych. Stąd też była używana druga nazwa na określenie jego funkcji - Vicarius in Pontificalibus (por. E. Sztafrowski, Biskupi koadiutorzy..., s. 57).

${ }^{49}$ Por. Tamże, kan. $353 \$ 1$.

${ }^{50}$ Biskup rezydencjalny udzielając biskupowi pomocniczemu pewnych prerogatyw o charakterze stałym, aż do chwili swej śmierci, zazwyczaj mianował go swym wikariuszem generalnym (por. I. Grabowski, Prawo kanoniczne według nowego Kodeksu, Lwów 1921, s. 249).

${ }^{51}$ Por. KPK/17, kan. $351 \S 4$.

52 Por. Tamże, kan. 354. 
biskupa pomocniczego wygasał $\mathrm{z}$ ustaniem urzędu biskupa rezydencjalnego, chyba, że w pismach apostolskich zarządzono inaczej ${ }^{53}$.

\subsection{Inne urzędy spełniane przez biskupów tytularnych}

Jak wspomniano wyżej z grona biskupów tytularnych wywodzili się niektórzy urzędnicy Kurii Rzymskiej. Przyjęło się bowiem, że dla podkreślenia ważności pełnionych przez nich urzędów, papież mianując kogoś na wyższe stanowisko kurialne, obdarzał go godnością biskupią, przydzielając mu tytuł którejś z nieistniejących już diecezji ${ }^{54}$.

Z biskupów tytularnych wywodzili się także legaci papiescy. Pozycja jaką zajmowała Stolica Apostolska na arenie międzynarodowej, domagała się, aby np. nuncjusza mianować arcybiskupem tytularnym, podkreślając przez to znaczenie zleconej mu misji ${ }^{55}$. Podobnie przedstawiała się sprawa urzędów kościelnych na terenach misyjnych, zwłaszcza wikariusza i administratora apostolskiego, którzy najczęściej byli biskupami ${ }^{56}$.

W podsumowaniu należy podkreślić, że prawodawca Kodeksu z 1917 roku przyczynił się do większej stabilizacji biskupów tytularnych w Kościele i precyzyjniej określił funkcje i urzędy, jakie mieli do spełnienia, a przez to bardziej ugruntował ich pozycję prawną. Należy

${ }^{53}$ Por. Tamże, kan. $355 \$ 2$. Kwestia wygaśnięcia urzędu biskupa pomocniczego wzbudzała wiele kontrowersji, bowiem nowy biskup rezydencjalny wcale nie musiał przyjąć go jako swego współpracownika i wówczas biskup pomocniczy zostawał bez urzędu, z czym wiązało się wiele problemów dla niego samego i całej diecezji, na terenie której przebywał. Pozostawał nadal biskupem, a właściwie funkcji biskupich nie mógł wykonywać. Problem ten został rozwiązany dopiero na II Soborze Watykańskim.

${ }_{54}$ Źródła tego typu postępowania należy upatrywać w tradycji mianowania biskupów na kluczowe urzędy, by podkreślić ich znaczenie w Kościele powszechnym. Nie było bowiem żadnego przepisu domagającego się lub zalecającego, by wyższe urzędy w Kurii Rzymskiej były przydzielane wyłącznie biskupom.

55 Por. F. Bączkowicz, Prawo Kanoniczne. Podręcznik..., s. 473.

${ }^{56}$ W sytuacji, gdy nie istniała jeszcze możliwość utworzenia normalnej diecezji, ale Kościół misyjny był już wystarczająco rozwinięty, że można mu było nadać określoną strukturę administracyjną, papież podnosząc prefekturę apostolską do rangi wikariatu apostolskiego mianował wikariusza biskupem tytularnym. 
też zauważyć, że mimo posiadanej godności biskupiej, nie mieli oni zbyt wielkich uprawnień. Ten rozdźwięk przejawiał się szczególnie w tym, że biskupi koadiutorzy bez prawa następstwa (pomocniczy), którzy stanowili większość episkopatu tytularnego w Kościele, tracili swój urząd wraz z ustaniem urzędu biskupa rezydencjalnego. Rozwiązanie tego problemu i większe dowartościowanie pozycji biskupów tytularnych przyniósł dopiero II Sobór Watykański ${ }^{57}$.

\section{Wpływ II Soboru Watykańskiego na zmianę pozycji prawnej biskupów tytularnych}

Wśród wniosków nadsyłanych na Sobór ${ }^{58}$ znalazły się także pewne sugestie związane $\mathrm{z}$ urzędem biskupa tytularnego. Postulowano przede wszystkim dowartościowanie przez przyszły Sobór tegoż urzędu ${ }^{59}$. Całość zagadnienia wymagała dyskusji soborowej, zwłaszcza co do roli urzędów biskupa koadiutora i biskupa pomocniczego ${ }^{60}$. W związku z tym pojawiła się propozycja, aby wyraźnie stwierdzić, że biskupi tytularni stanowią wraz z biskupami rezydencjalnymi

57 Por. E. Sztafrowski, Współpracownicy papieża w pasterskim posługiwaniu, Warszawa 1979, s. 176.

${ }^{58}$ Pap. Jan XXIII w dniu 25.01.1959 r. zapowiedział zwołanie Soboru powszechnego (AAS 51(1959) $68 \mathrm{nn}$. i rozpoczął się okres przygotowawczy. W czerwcu tego roku w imieniu Papieża wysłano listy do wszystkich kardynałów, arcybiskupów i biskupów, wikariuszy i prefektów apostolskich, wyższych przełożonych zakonnych oraz do uczelni kościelnych z prośbą o nadsyłanie propozycji w sprawie określenia problemów, którymi powinien się zająć przyszły Sobór (por. T, PAWLuk, Prawo kanoniczne według Kodeksu Jana Pawła II, t. I, Olsztyn 1985, s. 126).

${ }^{59} \mathrm{O}$ randze i znaczeniu biskupa tytularnego dla Kościoła świadczył fakt, że wśród bardzo wielu wniosków tylko jeden biskup wniósł projekt, by ten urząd został zlikwidowany (Por. Acta et Documenta Concilio Oecumenico Vaticano II apparando, Series I, Antepreaparatoria, Appendix vol. II, s. 417).

${ }^{60}$ Mimo iż urzędy te funkcjonowały w Kościele na podstawie przepisów Kodeksu z 1917 r. to jednak w początkowej fazie prac nad konstytucją Lumen gentium biskupi tytularni nie byli brani pod uwagę jako pełnoprawni członkowie Kolegium Biskupów (por. Schemata Constitutiones et Decretorum de quibus disceptatibus in Concilii sessionibus, Series secunda: de Ecclesia et de B. Maria Virgine, Typis Polyglottis Vaticanis 1962). 
kolegium następców Apostołów, które z prawa Bożego zajmuje miejsce Kolegium Apostołów, chociaż aktualnie nie wykonują oni w swoich diecezjach jurysdykcji ${ }^{61}$. Kolejny postulat dotyczył kwestii, aby oprócz ścisłego określania uprawnień tych biskupów przy nominacji ustanawiać ich na mocy prawa wikariuszami generalnymi, a wraz ze śmiercią biskupa administratorami apostolskimi diecezji ${ }^{62}$. Inne propozycje dotyczyły większej autonomii urzędu biskupa pomocniczego. Chodziło o to, że biskupi pomocniczy razem z ordynariuszem powinni współdziałać w zarządzaniu diecezją, zwłaszcza w wielkich diecezjach, aby godność biskupia nie była pomniejszana, ani biskup nie miał przeszkód w przyczynianiu się do dobra diecezji ${ }^{63}$. Jeszcze inne postulaty dotyczyły zwiększenia liczby biskupów pomocniczych. Powiększenie ich liczby mogło stwarzać jednak nowe nieporozumienia, dlatego postulowano, aby lepiej określić normy dotyczące statusu biskupa pomocniczego, ponieważ wielu $\mathrm{z}$ nich na stałe pełniło urzędy proboszczowskie ${ }^{64}$. Postulowano też, aby biskupi pomocniczy po otrzymaniu nominacji prowadzili swą działalność w zależności od biskupa rezydencjalnego. Dotyczyło to zwłaszcza ich funkcji w wielkich miastach i regionach, których podział administracyjny stwarzał szczególne trudności w koordynacji zarządzania ${ }^{65}$.

Ojcowie po rozpoczęciu prac Soboru stanęli, więc przed istotnymi problemami związanymi z doktryną o episkopacie. Chodziło o wypracowanie jasnej teologii biskupstwa. W związku z tym musieli udzielić odpowiedzi na pytania ściśle wiążące się z sakramentalnością konsekracji biskupiej i przynależności do Kolegium Biskupów. Innym problemem związanym z episkopatem była kwestia odpowiedzialności i zadań biskupów w Kościele powszechnym. Wreszcie Sobór musiał dokładnie wskazać, jaką pozycję prawną zajmują biskupi

\footnotetext{
${ }^{61}$ Por. Acta et Documenta Concilio Oecumenico Vaticano II apparando, Series I, Antepreaparatoria, Appendix vol. II, s. 417, nr 1.

${ }^{62}$ Por. Tamże, s. 418, nr 3.

${ }^{63}$ Por. Tamże, s. 419, nr 1.

${ }^{64}$ Por. Tamże, s. 419, nr 4 i 5.

${ }^{65}$ Por. Tamże, s. 419, nr 2.
} 
tytularni w Kościele powszechnym. Problem ten wiązał się z nauką o sakramentalności sakry biskupiej i przynależności do Kolegium Biskupów.

Podstawowe prawdy w tym zakresie zostały przedstawione w Konstytucji Lumen gentium w nr 21 i 22 w jej III rozdziale zatytułowanym „O hierarchicznym ustroju Kościoła, a w szczególności o episkopacie"66. Dla pełniejszego zrozumienia sakramentalności sakry biskupiej należy wspomnieć o jej związku z kapłaństwem Jezusa Chrystusa. Konstytucja podkreśla, że istnieje tylko jeden Najwyższy i Wieczny Kapłan Jezus Chrystus i jedno tylko kapłaństwo, kapłaństwo Chrystusowe ${ }^{67}$. Istnieje jednak dwojaka możliwość uczestnictwa w Chrystusowym kapłaństwie. Jednym ze sposobów jest uczestnictwo we wspólnocie, czyli w powszechnym kapłaństwie, do którego przynależą wszyscy ochrzczeni. Drugim jest kapłaństwo hierarchiczne, czyli służebne, do którego Chrystus wzywa łaską swego powołania ${ }^{68}$. Kapłaństwo hierarchiczne przekazał Chrystus za pośrednictwem Apostołów w różnym stopniu i różnym jednostkom, którzy od starożytności noszą nazwę biskupów, prezbiterów i diakonów ${ }^{69}$. Sobór podkreśla, że przez konsekrację biskupią udziela się pełni sakramentu kapłaństwa, która zarówno w tradycji liturgicznej Kościoła jak i w wypowiedziach świętych ojców nazywana jest najwyższym kapłaństwem bądź pełnią świętego posługiwania ${ }^{70}$. Skutek konsekracji jest potrójny. Każdy konsekrowany biskup uczestniczy we władzy

${ }^{66}$ Rozdział III można uważać za najbardziej zachowawczy. Podtrzymuje on bowiem w całości naukę Soboru Watykańskiego I. Jest natomiast prekursorski w stosunku do praktyki, jaka istniała w Kościele katolickim po tamtym Soborze, kiedy to biskupów traktowano niemal jak wikariuszy dykasterii rzymskich (por. E. Ozorowski, Wprowadzenie do Konstytucji dogmatycznej o Kościele, w: Sobór Watykański II Konstytucje Dekrety Deklaracje, Pallottinum 2002, s. 101).

${ }_{67}$ Por. Konstytucja Lumen gentium, nr 10.

${ }_{68}$ Por. M. KoŁodziejczy K, Sakramentalność episkopatu, w: Idee przewodnie soborowej Konstytucji o Kościele, Kraków 1971, s. 192.

${ }^{69}$ Por. Konstytucja Lumen gentium, nr 28.

${ }^{70}$ Por. Tamże, nr 21. Szerzej na ten temat por. E. SzTAfrowski, Kolegialność biskupów..., s. 37. 
nauczania, uświęcania i rządzenia. Biskupi przejmują rolę samego Chrystusa i w Jego zastępstwie działają ${ }^{71}$. Sobór nie czyni żadnego rozróżnienia pomiędzy biskupami diecezjalnymi i tytularnymi, lecz jasno stwierdza, że zadania te otrzymuje każdy biskup w momencie konsekracji. Tylko konsekracja daje pełnię mocy Ducha Świętego ${ }^{72}$, która została wylana na Apostołów przez Chrystusa w Dniu Pięćdziesiątnicy. Święcenia zaś prezbiteratu i diakonatu udzielają jej tylko częściowo.

Biskupi więc z ustanowienia Bożego stali się następcami Apostołów jako pasterze Kościoła i tworzą na wzór kolegium apostolskiego jedno Kolegium Biskupów. Stąd też funkcja pasterzowania może być wykonywana tylko w hierarchicznej wspólnocie z Głową Kolegium i jego członkami ${ }^{73}$. W ten sposób Sobór rozstrzygnął istotny problem przynależności do Kolegium Biskupów. Oprócz papieża jako głowy, pełniącego rolę osoby nadrzędnej, w skład kolegium wchodzą wszyscy prawnie wyświęceni biskupi, jako pełnoprawni jego członkowie. Wynika więc z tego, że każdy konsekrowany biskup jest w pierwszym rzędzie członkiem kolegium, a dopiero na drugim planie jest pasterzem Kościoła partykularnego ${ }^{74}$. Prymat papieża nie zwalnia z odpowiedzialności poszczególnych biskupów ani nie wchłania ich zadań, kolegialność nie przytłacza tego, co indywidualne. Biskup wchodząc do kolegium biskupiego, wnosi do niego osobiste dary i korzysta z dobra wspólnego, troszczy się o powierzoną sobie wspólnotę i ma na uwadze dobro całego Kościoła ${ }^{75}$. Nauka zawarta w Konstytucji Lumen gentium położyła kres błędnym poglądom na temat istoty i roli biskupa w życiu Kościoła i otworzyła tym samym drogę do uaktywnienia całego episkopatu.

${ }^{71}$ Por. Konstytucja Lumen gentium, nr 21.

${ }^{72}$ Por. Tamże.

${ }^{73}$ Por. Tamże.

${ }^{74}$ Por. E. Sztafrowski, Kolegialność biskupów..., s. 48-51; S. Nagy, Soborowa nauka o kolegialności władzy w Kościele, w: Idee przewodnie soborowej Konstytucji o Kościele, Kraków 1971, s. 229-230.

${ }^{75}$ Por. E. Ozonowski, Wprowadzenie do Konstytucji..., s. 102. 
Nauka wyżej zasygnalizowana została szerzej wyłożona w soborowym Dekrecie o pasterskich zadaniach biskupów w Kościele Christus Dominus $^{76}$. Czerpiąc z nauki o kolegialności dekret stwierdza, że stan biskupi, który jest następcą Kolegium Apostolskiego, stanowi również z głową swoją, Biskupem Rzymskim, a nigdy bez niego, podmiot najwyższej pełnej władzy nad całym Kościołem ${ }^{77}$. Mocą tego stwierdzenia została rozstrzygnięta kwestia udziału biskupów w soborach powszechnych. Udział ten z mocy prawa przysługuje wszystkim biskupom jak członkom Kolegium. Dekret Christus Dominus podkreśla też znaczenie Konferencji Biskupów i synodów partykularnych, które są płaszczyznami współpracy biskupów i znakiem jedności między biskupami. Zwłaszcza, jeśli chodzi o Konferencje Biskupów, Dekret stanowi, że będą je tworzyli, oprócz biskupów ordynariuszy, także wszyscy biskupi koadiutorzy i pomocniczy oraz inni biskupi tytularni pełniący specjalne zadania zlecane im przez Stolicę Apostolską lub Konferencje Biskupów. Pozostali biskupi tytularni oraz legaci papiescy nie posiadają prawa udziału w zebraniach Konferencji, lecz mogli być na nie zapraszani. Wszystkim ordynariuszom i biskupom koadiutorom przyznaje głos decydujący, innym natomiast głos doradczy bądź decydujący zależnie od postanowień statutu Konferencji ${ }^{78}$. Dekret wprowadzał, więc tym samym różnicę między biskupami koadiutorami a pomocniczymi. Kwestia ta uległa zmianie po Soborze Watykańskim II.

Z powyższych rozważań wynika wyraźnie, że urząd biskupa tytularnego został przez Sobór mocno dowartościowany. Potwierdza to przede wszystkim udział tych biskupów w pełni kapłaństwa Chrystusa, którą otrzymują wraz z przyjęciem sakry biskupiej. Przejawiło się to także w innych decyzjach Soboru, który ustanowił biskupów

${ }^{76}$ Por. Sobór Watykański II, Dekret o pasterskich zadaniach biskupów w Kościele Christus Dominus, w: Sobór Watykański II Konstytucje Dekrety Deklaracje, Pallottinum 2002, s. 236-258.

77 Por. Tamże, nr 4.

${ }^{78}$ Por. Tamże, nr 37 i 38. Na temat kształtowania się pozycji biskupów tytularnych w ramach Konferencji Biskupów por. E. SzTAfrowski, Konferencje Biskupie, Warszawa 1984. 
tytularnych pełnoprawnymi członkami Kolegium Biskupów z głosem decydującym. Wiąże się z tym zwiększona odpowiedzialność i troska zarówno o Kościół powszechny jak i o Kościoły partykularne. Znaczenie urzędu biskupa tytularnego zostało podkreślone też w przyznaniu mu udziału w synodach partykularnych, a zwłaszcza w Konferencjach Biskupów, chociaż w tych ostatnich w sposób zróżnicowany.

\section{Postanowienia II Soboru Watykańskiego i ustawodawstwa posoborowego dotyczące biskupów koadiutorów i pomocniczych}

Zgodnie z przedstawioną przez Sobór teologią biskupstwa musiały nastąpić zmiany w spojrzeniu na urzędy pełnione przez biskupów tytularnych w diecezjach, czyli biskupów koadiutorów i pomocniczych $^{79}$. Postanowienia w tej materii znalazły się w Dekrecie Christus Dominus, gdzie zapisano, iż chociażby w piśmie nominacyjnym nie było z góry postanowione, niech biskup diecezjalny ustanowi swego biskupa pomocniczego, czy biskupów pomocniczych wikariuszami generalnymi lub przynajmniej wikariuszami biskupimi ${ }^{80}$. Ponadto postanowiono, aby biskupi koadiutorzy i pomocniczy zawsze okazywali uległość i szacunek biskupowi diecezjalnemu, który ze swej strony powinien po bratersku ich miłować i mieć dla nich poważanie ${ }^{81}$. Inaczej rozwiązano także kwestię pozycji biskupa pomocniczego podczas wakatu stolicy biskupiej. Jak wiadomo wszyscy biskupi współpracownicy, którzy nie mieli prawa następstwa, tracili z chwilą wakatu wszystkie swoje prawa ${ }^{82}$. Ojcowie Soboru opierając się na soborowej teologii biskupstwa postulowali, aby ta sytuacja uległa całkowitej zmianie. Zaproponowano, aby podczas wakatu diecezji biskup pomocniczy nie tracił żadnych praw, które zostały mu przyznane przez

\footnotetext{
${ }^{79}$ Szerzej na ten temat por. J. SoкоŁowsкi, Urząd biskupa pomocniczego w prawie powszechnym Kościoła łacińskiego. Studium historyczno-prawne, Warszawa 2014.

${ }^{80}$ Por. Dekret Christus Dominus, nr 26.

${ }^{81}$ Por. Tamże, nr 25.

82 Por. KPK/17, kan. $355 \$ 2$.
} 
byłego biskupa ${ }^{83}$. W efekcie w Dekrecie Christus Dominus znalazło się postanowienie w tej materii ${ }^{84}$. Także i powyższe decyzje Soboru wyraźnie wskazują na wzmocnienie pozycji biskupów tytularnych poprzez dowartościowanie urzędu biskupa koadiutora, a zwłaszcza pomocniczego. Wzrost rangi i kompetencji tych urzędów ma swoje źródło w soborowej nauce o episkopacie.

Jak łatwo można zauważyć wskazania Soboru dotyczące biskupów tytularnych i urzędów przez nich wykonywanych miały charakter bardzo ogólny. Ich sprecyzowaniu służyło szczegółowe ustawodawstwo posoborowe. Stolica Apostolska wydała szereg dokumentów, które regulowały konkretne kwestie i wprowadzały w życie zalecenia Soboru. Jednym z pierwszych dekretów wykonawczych było Motu proprio Ecclesiae Sanctae wydane przez papieża Pawła VI dnia 6 sierpnia 1966 roku $^{85}$. Papież nawiązując do postanowienia nr 25 Dekretu Christus Dominus podkreślił w Motu proprio konieczność ustanawiania biskupa pomocniczego, ilekroć domagają się tego potrzeby apostolatu. W nawiązaniu do nr 26, w którym zalecano, aby biskupi tytularni w czasie wakatu stolicy biskupiej nie tracili władzy i uprawnień, prawodawca stanowił, że również biskup pomocniczy, który nie został wybrany tymczasowym rządcą diecezji wakującej,

${ }^{83} \mathrm{Już}$ w pierwszym schemacie Dekretu Christus Dominus proponowano, aby podczas wakatu funkcja administratora diecezji lub wikariusza kapitulnego mogła być powierzana biskupowi pomocniczemu, a jeżeli jest ich kilku, jednemu z nich (por. Schemata Constitutionum et Decretorum ex quibus in Concilio disceptanta seligentur, Series III, kaput I, s. 78, nr 17).

${ }^{84}$ Por. Dekret Christus Dominus, nr 26: „O ile by kompetentna władza nie zdecydowała inaczej, to wraz z obowiązkami biskupa diecezjalnego nie wygasają władze i uprawnienia, w które są wyposażeni na mocy prawa biskupi pomocniczy. Pożądane jest również, by w razie wakującej stolicy biskupiej, obowiązek zarządzania diecezją powierzono biskupowi pomocniczemu, lub jeśli jest ich wielu, to jednemu z nich, chyba że poważne powody wskazywałyby co innego".

${ }^{85}$ Por. Paulus VI, Motu proprio Ecclesiae Sanctae, AAS 58(1966) 757-787, tekst polski w Posoborowe Prawodawstwo Kościelne, opr. E. Sztafrowski, t. I, z.1, nr 54178 (dalej PPK). Motu proprio zawierało normy wykonawcze do czterech Dekretów soborowych: Christus Dominus, Presbyterorum Ordinis, Perfectae caritatis i Ad gentes divinitus. 
cieszy się nadal uprawnieniami przyznanymi mu przez prawo, aż do chwili objęcia władzy przez nowego biskupa diecezjalnego ${ }^{86}$. Także idąc w ślad za postanowieniem nr 21 Dekretu Christus Dominus, który zalecał biskupom diecezjalnym rezygnację z urzędu, dla dobra diecezji, z racji podeszłego wieku lub ze względu na zły stan zdrowia, Motu proprio nakazywało wszystkim biskupom, aby po ukończeniu 75 roku życia rezygnowali z urzędu na ręce kompetentnej władzy, która ostatecznie miała wydać decyzję, biorąc pod uwagę okoliczności towarzyszące poszczególnym przypadkom. W razie przyjęcia rezygnacji diecezja, w której dotychczas pracowali miała zapewnić im godziwe utrzymanie. Tym samym biskupi ci stawali się biskupami emerytami ${ }^{87}$. Powyższe postanowienie dotyczące emerytury biskupów odnosiły się także do biskupów tytularnych, którzy sprawowali urzędy biskupów koadiutorów i pomocniczych.

Papież Paweł VI oprócz zmian w strukturach diecezjalnych wprowadził po Soborze także zmiany w Kurii Rzymskiej, wydając najpierw Motu proprio Pro comperto sane z dnia 6 sierpnia 1967 roku $^{88}$, a następnie 15 sierpnia tegoż roku Konstytucję apostolską Regimini Ecclesiae universae ${ }^{89}$. Zmiany te jednak dotyczyły funkcjonowania Kurii i nie miały wpływu na nominacje na kurialne urzędy, które zajmowali głównie biskupi tytularni.

Innym dokumentem wydanym podczas trwania Soboru Watykańskiego II było Motu proprio Pastorale munus z dnia 30 listopada 1963 roku $^{90}$, na mocy którego papież Paweł VI udzielił wszystkim biskupom pewnych uprawnień i przywilejów, aby bardziej uwydatnić ich godność biskupią i jednocześnie uczynić skuteczniejszym oraz sprawniejszym ich urząd pasterski.

\footnotetext{
${ }^{86}$ Por. Motu proprio Ecclesiae Sanctae, nr $13 \$ 1-3$ (PPK, t. I, z. 1, nr 73).

${ }^{87}$ Por. Tamże, nr 11 (PPK, t. I, z. 1, nr 71).

${ }^{88}$ Por. Paulus VI, Motu proprio Pro comperto sane, AAS 59(1967) 881-884 (PPK, t. II, z. 1, nr 1455-1468).

89 Por. Paulus VI, Constitutio apostolica Regimini Ecclesiae universae, AAS 59(1967) 885-928 (PPK, t. II, z.1. nr 1469-1692).

90 Por. Paulus VI, Motu proprio Pastorale munus, AAS 56(1964) 5-12 (PPK, t. I, z. 1, nr 1-52).
} 
W kontekście omawianego zagadnienia ważnym wydarzeniem było ustanowienie Synodu Biskupów, który jest organem gromadzącym cały episkopat. Zgodnie z Motu proprio Apostolica Sollicitudo z 15 września $1965 \mathrm{roku}^{91}$, Synod ma być przedstawicielem całego episkopatu katolickiego, niosącym wieloraką pomoc w kierowaniu Kościołem powszechnym. Wewnętrzna struktura Synodu uwzględnia udział w obradach także biskupów tytularnych, a zgodnie z regulaminem Synodu biskupi ci mogą brać udział w Synodzie będąc przedstawicielami episkopatów krajowych podczas sesji zwyczajnej i specjalnej lub być członkami Synodu na podstawie nominacji papieskiej ${ }^{92}$.

Wyrazem jedności i współpracy biskupów są także Konferencje Biskupów poszczególnych krajów, których status prawny określił Dekret Christus Dominus ${ }^{93}$. Także i tutaj należy zauważyć nowe rozwiązanie prawne dotyczące biskupów tytularnych, bowiem wszyscy biskupi, aczkolwiek w sposób zróżnicowany mają udział w pracach Konferencji. To zróżnicowanie dotyczy posiadania głosu decydującego czy tylko doradczego. Większość statutów krajowych Konferencji Europy przyznaje biskupom tytularnym głos decydujący we wszystkich sprawach, w których kompetentne są Konferencje $e^{94}$. Inne przewidują określone ograniczenia tylko do niektórych spraw ${ }^{95}$. Drugą sprawą jest możliwość przewodniczenia Konferencji przez biskupa tytularnego. W tej kwestii również większość statutów stanowi, że wszyscy biskupi

${ }^{91}$ Por. Paulus VI, Motu proprio Apostolica Sollicitudo, AAS 57(1965) 775-780 (PPK, t. I, z. 1. nr 297-314).

92 Por. Secretaria Status, Ordo Synodi Episcoporum celebrandae, AAS 59(1967) 91-103 (PPK, t. I, z. 1, nr315- 397).

${ }_{93}$ Por. Dekret Christus Dominus, nr 38.

${ }_{94}$ Por. Gli Statuti delle Conferenze Episcopali, t. I, Europa, opr. R. Astori, Padwa 1987.

${ }^{95} \mathrm{~Np}$. Statut Konferencji Wielkiej Brytanii nie udziela biskupom tytularnym głosu decydującego w sprawach finansowych. Zgodnie ze Statutem Konferencji Episkopatu Polski na zebraniach plenarnych wszystkim członkom Konferencji przysługuje głos decydujący, z wyjątkiem uchwalania statutu lub dokonywania w nim zmian, kiedy to głos decydujący posiadają tylko biskupi diecezjalni i prawnie z nimi zrównani oraz koadiutorzy (por. Statut Konferencji Episkopatu Polski, art. 16). 
należący do Konferencji są potencjalnymi kandydatami na urząd jej przewodniczącego, jednak statuty niektórych Konferencji urząd ten rezerwują tylko dla biskupów diecezjalnych ${ }^{96}$.

W omawianej materii należy też przywołać Dyrektorium Ecclesiae imago wydane w dniu 22 lutego 1973 roku ${ }^{97}$ przez Kongregację Biskupów, poświęcone pasterskiej posłudze wykonywanej przez biskupów w poszczególnych diecezjach. Czerpiąc z nauki Soboru Kongregacja kładzie nacisk na współpracę pomiędzy biskupem diecezji a jego pomocnikami ${ }^{98}$. Podkreśla zadania, jakie w tym względzie spoczywają na biskupie diecezjalnym, zachęcając go do tego, aby podejmował współpracę z biskupem koadiutorem i biskupami pomocniczymi, jeśli takich posiada. Współpraca ta ma iść w tym kierunku, by przyznając władzę swym współpracownikom, biskup wziął pod uwagę dobro pasterzowania, jedność rządzenia diecezją, wspólny sakrament święceń oraz fakt, że biskupi pomocniczy są członkami kolegium biskupiego. Ponadto Dyrektorium podaje także szczegółowe zadania w tej materii. Do tych zadań należą: spotkania z biskupami pomocniczymi w ustalonych terminach, wymiana wzajemnych informacji na temat diecezji, odbywanie narad, omawianie projektowanych zamierzeń oraz podtrzymywanie wspólnoty ducha.

\section{Biskupi tytularni w świetle Kodeksu Jana Pawła II i dokumentów pokodeksowych}

Promulgowany przez pap. Jana Pawła II w dniu 25 stycznia 1983 roku Kodeks Prawa Kanonicznego, w księdze II definiuje urząd biskupa w Kościele łacińskim. Prawodawca stanowi, że biskupi z Bożego

${ }^{96}$ Np., Statuty Konferencji Biskupów Niemiec, Austrii, Szkocji, Węgier, Malty, Hiszpanii. Podobne stanowisko zajmuje Konferencja Episkopatu Polski. (por. Statut Konferencji Episkopatu Polski, art. 26).

${ }^{97}$ Por. Sacra Congregatio pro Episcopis, Directorium de pastorali ministerio episcoporum Ecclesiae imago, Typis Polyglottis Vaticanis 1973 (PPK, t. VI, z. 1. nr 10370-11035).

98 Por. Dyrektorium Ecclesiae imago wśród osób i instytucji współpracujących bezpośrednio z biskupem diecezjalnym na pierwszym miejscu w nr 199 wymienia biskupów koadiutorów i pomocniczych. 
postanowienia są następcami Apostołów i przez Ducha Świętego, który został im dany, są ustanowieni w Kościele pasterzami, ażeby byli nauczycielami, kapłanami świętego kultu i sprawującymi posługę rządzenia ${ }^{99}$. W cytowanym kanonie tenże prawodawca czerpiąc $z$ nauki Soboru podkreśla potrójne zadania (munus), jakie spoczywają na każdym biskupie. Paragraf drugi tegoż kanonu dokładnie to precyzuje $^{100}$. Należy zauważyć, że cytowany kanon jest kontynuacją myśli Soboru Watykańskiego II i stanowi dowartościowanie urzędu biskupa tytularnego, poprzez podkreślenie godności sakry biskupiej i wspólnoty kolegium biskupiego. Mimo to jednak Kodeks nadal trzyma się tradycji, wyróżniając biskupów diecezjalnych, czyli pasterzy diecezji i biskupów tytularnych ${ }^{101}$.

Jeśli chodzi o sposoby mianowania biskupów, nowy Kodeks precyzuje sprawę następująco: „Papież mianuje biskupów w sposób nieskrępowany albo zatwierdza wybranych zgodnie z prawem"102. Wymagania, jakie prawodawca nowego Kodeksu stawia kandydatom na urząd biskupa, nie uległy zasadniczej zmianie. Jedynie pominięto wymóg prawego pochodzenia i podwyższono wiek kandydata do 35 lat, czyli o 5 lat wyższy niż w starym prawie. Inne wymogi są identyczne jak w poprzednim Kodeksie ${ }^{103}$. Podobnie jak w Kodeksie z 1917 r. przymioty kandydata mają być stwierdzone drogą procesu informacyjnego de vita et moribus. Ostateczny zaś osąd co do jego zdatności należy do Stolicy Apostolskiej ${ }^{104}$.

Wśród obowiązków należących do nominata prawodawca wylicza dwa: przyjęcie sakry biskupiej przed objęciem urzędu w ciągu trzech miesięcy od otrzymania pisma nominacyjnego, chyba że zaistniałaby

\footnotetext{
99 Por. KPK/83, kan. $375 \$ 1$.

${ }^{100}$ Por. Tamże kan. 375 \$ 2: „Przez samą konsekrację biskupią otrzymują biskupi wraz z zadaniami uświęcania, także zadania nauczania i rządzenia, które z natury swojej mogą być wykonywane tylko w hierarchicznej wspólnocie z Głową Kolegium i jego członkami”.

${ }^{101}$ Por. Tamże, kan. 376.

102 Por. Tamże, kan. $377 \$ 1$.

${ }^{103}$ Por. KPK/17, kan. $331 \$ 1$ i KPK/83, kan. $378 \$ 1$.

104 Por. KPK/83 kan. $378 \$ 2$.
} 
prawna przeszkoda uniemożliwiająca spełnienie tego wymogu oraz złożenie wyznania wiary i przysięgi wierności Stolicy Apostolskiej według formuły przez nią zatwierdzonej ${ }^{105}$.

W nowym Kodeksie znalazły potwierdzenie przepisy ustawodawstwa posoborowego dotyczące przejścia biskupów na emeryturę. Tak więc do wszystkich biskupów prawodawca zwraca się z prośbą, aby z chwilą ukończenia 75 roku życia składali rezygnację z zajmowanego urzędu. Decyzja o przyjęciu rezygnacji należy wyłącznie do papieża. Prośba ta dotyczy także biskupów, którzy z powodu choroby lub innej poważnej przyczyny nie mogą spełniać należycie swych obowiązków ${ }^{106}$. Z chwilą przyjęcia rezygnacji, gdy idzie o biskupa diecezjalnego przyjmuje on tytuł emeryta swojej diecezji. Troska o jego dalszy los, czyli odpowiednie i godne utrzymanie, należy do diecezji, w której dotychczas pracował, zachowując w niej zgodnie z własnym życzeniem mieszkanie ${ }^{107}$ lub do Konferencji Biskupów, chyba, że Stolica Apostolska zadecyduje inaczej ze względu na specjalne okoliczności ${ }^{108}$.

Przedstawione wyżej postanowienia kodeksowe odnoszą się do wszystkich biskupów, którzy przez przyjęcie sakramentalnej sakry w łączności z Głową Kolegium i jego członkami, spełniają urząd biskupi w Kościele. Różnica między biskupami pojawia się z racji konkretnych zadań, jakie są im powierzane w Kościele. W przypadku biskupa diecezjalnego powierza się mu diecezję, w której przysługuje mu władza zwyczajna, własna i bezpośrednią, za wyjątkiem jedynie tych spraw, które są zarezerwowane papieżowi lub innej władzy

\footnotetext{
105 Por. Tamże, kan. 379 i 380.

106 Por. Tamże, kan. 401 i kan. 411.

107 Por. Tamże, kan. $402 \$ 1$.

108 Por. Tamże, kan. $402 \$ 2$ i kan 411. Należy zauważyć, że prawodawca kodeksowy postanowienia zawartego w kan. $402 \$ 1$ nie odnosi do biskupów tytularnych, o czym stanowi kan. 411 przywołując tylko postanowienie kan. $402 \$ 2$. Stąd należy wyciągnąć wniosek, że po przyjęciu zrzeczenia biskup koadiutor i pomocniczy nie otrzymują tytułu emeryta diecezji, w której pracowali, chociaż obowiązek ich dalszego utrzymania spoczywa w pierwszym rzędzie na tej diecezji.
} 
kościelnej ${ }^{109}$. Zaś biskup tytularny pracujący w diecezji posiada władzę ograniczoną w stosunku do władzy biskupa diecezjalnego. Te ograniczenia pochodzą nie tylko ze strony samego prawa, ale także mogą pochodzić od biskupa diecezjalnego.

Ponadto biskupi pomocniczy są ustanawiani zazwyczaj na prośbę biskupa diecezjalnego, natomiast biskup koadiutor ustanawiany jest zwykle z urzędu przez Stolicę Apostolską. Tylko biskup koadiutor ma prawo następstwa. Mianowany na urząd biskupa koadiutora winien objąć go przez okazanie, osobiście lub przez pełnomocnika, pisma nominacyjnego biskupowi diecezjalnemu oraz kolegium konsultorów w obecności kanclerza kurii, który sporządza protokół. Jeśli zaś chodzi o biskupa pomocniczego, wystarczy okazanie pisma biskupowi diecezjalnemu w obecności kanclerza kurii, który winien sporządzić protokół. W sytuacji gdyby biskup był pozbawiony możliwości wykonywania swego urzędu, zarówno biskup koadiutor jak i biskup pomocniczy okazują pismo nominacyjne kolegium konsultorów w obecności kanclerza ${ }^{110}$.

Z chwilą objęcia urzędu na biskupie koadiutorze i pomocniczym spoczywają określone obowiązki względem diecezji, w której zostali ustanowieni jak i jej biskupa. Powinni oni je tak spełniać, aby w działaniu i w duchu zawsze być w łączności z biskupem diecezjalnym. Są zobowiązani wspomagać biskupa i jeśli nie tłumaczy słuszna przeszkoda zastępować go ilekroć tego żąda w wykonywaniu czynności pontyfikalnych i innych funkcji, które spoczywają na biskupie diecezjalnym ${ }^{111}$.

Zarówno biskup koadiutor jak i pomocniczy mają obowiązek rezydencji w diecezji, której nie powinni opuszczać za wyjątkiem urlopu wakacyjnego nieprzekraczającego jednego miesiąca lub gdyby chodziło o spełnienie jakichś obowiązków poza diecezją ${ }^{112}$.

\footnotetext{
109 Por. Tamże, kan. $381 \S 1$.

110 Por. Tamże, kan. 404.

${ }^{111}$ Por. Tamże, kan. $408 \$ 1$.

112 Por. Tamże, kan. 410.
} 
Biskupi tytularni jako szczególni i konieczni współpracownicy biskupa diecezjalnego są jego doradcami i powiernikami. Przede wszystkim oni powinni zajmować kierownicze stanowiska kurii diecezjalnej. Prawodawca kodeksowy idąc za wskazaniami Soboru zobowiązuje biskupa diecezjalnego do ustanowienia biskupa koadiutora lub biskupa pomocniczego mającego specjalne zadania wikariuszem generalnym. Im też powinien przed innymi osobami powierzać te sprawy, które na podstawie prawa wymagają specjalnego zlecenia ${ }^{113}$. Z nimi biskup diecezjalny winien omawiać sprawy większej wagi, mając na uwadze obecne i przyszłe dobro diecezji1" ${ }^{14}$. Jeśli zaś chodzi o pozostałych biskupów pomocniczych, prawodawca również nakazuje biskupowi diecezjalnemu ustanowić ich wikariuszami generalnymi lub przynajmniej wikariuszami biskupimi ${ }^{115}$. Powinni oni być również wzywani przez biskupa diecezjalnego, jeśli trzeba rozważyć ważniejsze sprawy diecezji1'. Zarówno biskup koadiutor jak i pomocniczy mają pierwszeństwo w sprawowaniu czynności biskupich. Biskup diecezjalny nie powinien ich zlecać komu innemu ${ }^{117}$.

Warto jeszcze podkreślić kwestię stałości urzędu biskupa koadiutora i biskupa pomocniczego podczas wakatu stolicy biskupiej. Z chwilą wakatu biskup koadiutor staje się biskupem diecezji, dla której został ustanowiony, byleby prawnie objął urząd ${ }^{118}$. W sytuacji wakatu nie ustaje też funkcja biskupa pomocniczego. $Z$ tej racji, iż wykonywał w imieniu biskupa diecezjalnego, którego już nie ma, urząd wikariusza generalnego lub biskupiego, traci te urzędy, ale do czasu objęcia diecezji przez nowego biskupa, zachowuje władzę i uprawnienia, które posiadał przed wakatem stolicy biskupiej jako wikariusz generalny lub biskupi. A gdyby nie został wybrany administratorem diecezjalnym, tę swoją władzę wykonuje w zależności od władzy

\footnotetext{
113 Por. Tamże, kan. $406 \$ 1$.

114 Por. Tamże, kan. $407 \$ 1$.

115 Por. Tamże, kan. $406 \$ 2$.

116 Por. Tamże, kan. $407 \$ 2$.

117 Por. Tamże, kan. $408 \$ 2$.

118 Por. Tamże, kan. $409 \$ 1$.
} 
administratora ${ }^{119}$. Ponadto prawodawca dowartościowując urząd biskupa pomocniczego stanowi, aby z chwilą wakatu, aż do czasu wyboru administratora diecezjalnego, rządy w diecezji sprawował biskup pomocniczy, a gdy jest ich kilku, najstarszy promocją ${ }^{120}$. Mimo, iż prawodawca nie zamieścił odrębnych przepisów na temat władzy biskupa pomocniczego w sytuacji przeszkodzenia stolicy biskupiej, to wydaje się, że w kwestii jego uprawnień zachodzi tu analogiczna sytuacja jak podczas wakatu ${ }^{121}$. Nowy biskup diecezjalny powinien zaakceptować biskupa pomocniczego, który był współpracownikiem jego poprzednika i mianować go wikariuszem generalnym lub wikariuszem biskupim.

Jeśli chodzi o udział biskupów tytularnych w pracach synodów partykularnych, to prawodawca kodeksowy wymienia ich jako stałych członków tych zgromadzeń z głosem decydującym ${ }^{122}$. Także biskupi tytularni z mocy prawa przynależą do Konferencji Biskupów. Otrzymują oni głos decydujący lub doradczy w zależności od postanowień statutu danej Konferencji ${ }^{123}$. Ponadto jest rzeczą oczywistą, że biskupi tytularni pełniący zadania na terenie jakiejś diecezji, czy to jako biskup koadiutor, czy też jako biskupi pomocniczy mają prawo, a nawet obowiązek uczestniczyć w pracach synodu diecezjalnego ${ }^{124}$.

Przeprowadzona analiza postanowień Kodeksu Jana Pawła II pozwala wyciągnąć wniosek, co do pozycji prawnej biskupów tytularnych w Kościele powszechnym i partykularnym. Otóż prawodawca precyzuje głównie ich sytuację w związku z pełnieniem przez nich urzędów: biskupa koadiutora i biskupa pomocniczego. Zgodnie

\footnotetext{
119 Por. Tamże, kan. $409 \$ 2$.

120 Por. Tamże, kan. 419.

${ }^{121}$ Por. Tamże, kan $413 \$ 1$.

${ }_{122}$ Por. Tamże, kan. 443.

${ }^{123}$ Por. Tamże, kan. $450 \$ 1$. W kwestii przynależności do Konferencji prawodawca podtrzymuje nadal stanowisko, że ci biskupi tytularni, którzy nie pełnią żadnej funkcji zleconej im przez Stolicę Apostolską lub Konferencję Biskupów z mocy prawa nie przynależą do niej (por. $\$ 2$ ). Wydaje się jednak, że jest to rzadki status biskupa tytularnego.

${ }^{124}$ Por. Tamże, kan. $463 \S 1$.
} 
z doktryną Soboru te urzędy zostały dowartościowane. Stały się urzędami stabilnymi i nienaruszalnymi, odzwierciedlając w ten sposób godność sakry biskupiej.

Należy jednak dodać, że pewne nowe naświetlenie urzędu biskupiego, w tym pozycji biskupów tytularnych przyniosły dokumenty pokodeksowe, do których należy zaliczyć Adhortację apostolską Pastores Gregis z dnia 16 października 2003 roku $^{125}$ i Dyrektorium Apostolorum Successores z dnia 22 lutego 2004 roku $^{126}$.

Adhortacja przedstawia teologiczne rozumienie powołania biskupa i roli, jaką pełni on w Kościele rzymskokatolickim, przede wszystkim jako sługi Ewangelii Jezusa Chrystusa dla nadziei świata. Cytowany dokument poświęcił też wiele miejsca duchowej formacji biskupiej, która jest rozumiana jako droga do świętości przeżywanej z ludem. Biskup ma być też heroldem nadziei opartej na Chrystusie i swoje zadania nauczania, uświęcania i kierowania wykonywać kolegialnie. Ta kolegialność posługi biskupiej jest budowana na różnych płaszczyznach: od Kościołów partykularnych poprzez zebranie Konferencji Episkopatu, synody partykularne, aż po synody biskupów i sobory zwoływane przez papieża ${ }^{127}$. Dokument podkreśla, że władza biskupa jest rozumiana jako munus pastorale i jest zakorzeniona w misji Chrystusa. Biskup bowiem jest zastępcą i legatem Chrystusa, który kieruje powierzoną sobie wspólnotą wiernych. Stąd też posługi biskupa nie

${ }^{125}$ Por. Jan Pawe II, Posynodalna Adhortacja apostolska Pastores Gregis o biskupiej posłudze Ewangelii Jezusa Chrystusa dla nadziei świata, tekst polski w: Ustrój hierarchiczny Kościoła. Wybór źródeł, opr. W. Kacprzyk, M. Sitarz, Lublin 2006, s. 310-400 (dalej PG). Jest ona owocem X Zwyczajnego Zgromadzenia Synodu Biskupów, który odbył się w Watykanie od 30 września do 27 października 2001 roku.

126 Por. Congreazione Per i Vescovi, Direttorio per il minister pastorale dei Vescovi Apostolorum Successores, Città del Vaticano 2004, tekst polski w: Ustrój hierarchiczny Kościoła. Wybór źródeł, opr. W. Kacprzyk, M. Sitarz, Lublin 2006, s. 517-711 (dalej AS). Dyrektorium obok nauki Soboru Watykańskiego II i Kodeksu Prawa Kanonicznego z 1983 roku, uwzględnia Adhortację Pastores Gregis, która podsumowuje prace Synodu Biskupów z 2001 roku. W swej treści nawiązuje do Dyrektorium Ecclesiae imago wydanym 31 lat wcześniej.

${ }^{127}$ Por. PG, nr 55 nn. 
można zredukować do zadań moderatora, ponieważ munus episcopale przedstawia jasno prawa i obowiązki rządzenia, w które jest wpisany element jurysdykcji. I chociaż wiele stwierdzeń zawartych w dokumencie można odnieść do wszystkich biskupów, także do biskupów tytularnych, to jednak element jurysdykcji dokument wyraźnie odnosi jedynie do posługi biskupa diecezjalnego. Mówiąc o pasterskich rządach biskupa Adhortacja wyraźnie przypomina nauczanie Soboru Watykańskiego II zawarte w Dekrecie Christus Dominus ${ }^{128}$.

Z kolei Dyrektorium Apostolorum Successores w sposób również pogłębiony duchowo traktuje o tożsamości i posłudze biskupa, jego trosce o Kościół powszechny oraz o wymiarze kolegialnym misji pasterskiej. Mówiąc o pasterskich rządach biskupa zajmuje podobne stanowisko jak wyżej omówiona Adhortacja i odnosi je tylko do biskupa diecezjalnego ${ }^{129}$. Pewną nowością w Dyrektorium jest mowa o obowiązkach i prawach biskupa emeryta i w Aneksie o wakansie stolicy biskupiej. Należy zwrócić uwagę na wyjaśnienie zawarte w dokumencie w kwestii statusu biskupa emeryta, że o ile biskup diecezjalny od momentu ogłoszenia przyjęcia rezygnacji zachowuje ipso iure tytuł biskupa emeryta swojej diecezji, o tyle biskup pomocniczy zachowuje tytuł swojej stolicy tytularnej z przydaniem określenia „były biskup pomocniczy” diecezji ${ }^{130}$. Warto też dodać, co jest nowością, że dyrektorium wymienia obowiązki biskupa emeryta w odniesieniu do munera biskupich, a także w odniesieniu do Kościoła partykularnego i powszechnego. Niektóre z nich dotyczą także biskupów tytularnych. Jeśli chodzi zaś chodzi o ich pozycję prawną Dyrektorium nie zawiera żadnych nowości i nie wychodzi poza ustalenia zawarte w doktrynie Soboru Watykańskiego II oraz w postanowieniach Kodeksu Jana Pawła II. Świadczy o tym fakt, że przy omawianiu posługi biskupiej często odwołuje się do dokumentów Soboru Watykańskiego II i Kodeksu Jana Pawła II, a traktując

\footnotetext{
${ }_{128}$ Por. Tamże, nr 42, 47 i nn.

${ }^{129}$ Por. AS, nr $159 \mathrm{nn}$.

${ }^{130}$ Por. Tamże, nr 226.
} 
o biskupie emerycie i wakansie stolicy biskupiej w przypisach prawie wyłącznie przywołuje kanony tegoż Kodeksu.

Z pewnością prawodawca kodeksowy, w oparciu o doktrynę II Soboru Watykańskiego, a także dokumenty pokodeksowe w wielu aspektach dowartościowały pozycję prawną biskupów tytularnych, ale czy dokonały jej radykalnej zmiany? Pytanie to pozostaje nadal pytaniem otwartym.

\section{Zakończenie}

W opracowaniu dokonano analizy przepisów dotyczących pozycji prawnej biskupów tytularnych w Kościele łacińskim. Analiza historycznych tekstów prawnych pozwoliła dojść do wniosku, że od początku pojawienia się biskupów tytularnych istniały duże kontrowersje wokół ich pozycji prawnej, a szczególnie zadań i kompetencji. Wynikały one z założenia i wcześniejszej praktyki Kościoła, że każda diecezja powinna mieć tylko jednego biskupa. Posiadali, więc oni jurysdykcję w opuszczonych diecezjach, której nie mogli wykonywać $\mathrm{w}$ diecezjach, do których przybyli. Byli więc mianowani na diecezje, które opuścili z nadzieją powrotu do nich. Szybko jednak sprawdziła się ich przydatność, a nawet konieczność w nowych diecezjach. Stąd pojawiła się praktyka mianowania biskupów koadiutorów i biskupów pomocniczych, ale ich pozycja była ciągle niedowartościowana. Radykalna zmiana ich pozycji dokonała się w ramach prac i doktryny II Soboru Watykańskiego na temat sakramentalności sakry biskupiej i kolegialności biskupów. Sobór przyznał wszystkim biskupom zasadniczą równość w Kościele. Przejawia się ona przede wszystkim w prawie do udziału w Soborze powszechnym, Synodzie Biskupów, w pracach Kurii Rzymskiej. Także ich pozycja w Kościele partykularnym uległa zmianie. Postanowienia nowego Kodeksu znacznie dowartościowały pozycję prawną biskupów tytularnych, ale nie dokonały radykalnej zmiany, która zamykałaby dyskusję dotyczącą roli i zadań biskupów tytularnych w Kościele. Dokumenty pokodeksowe wprawdzie pogłębiły warstwę duchową posługi biskupiej w Kościele nie wniosły jednak nic nowego od strony prawnej. 


\section{Titular Bishops in the Law of the Latin Church}

The author in his study analysed the legal position of titular bishops in the Latin Church. His analysis of historical legal texts led to the conclusion that from the beginning of the appearance of the titular bishops there was a great controversy around their legal status and tasks. They stemmed from the church's assumption and previous practice that each diocese should have only one bishop. So they had jurisdiction in abandoned dioceses that they could not exercise in the dioceses they came to. They were appointed to dioceses they had left with the hope of returning to them. However, their helpfulness and sometimes necessity in the new dioceses also proved to be functional. Hence the practice of appointing coadjutor bishops and auxiliary bishops, nonetheless their position was still undervalued. Their apprizement took place within the framework of the doctrine of the Second Vatican Council on the sacramentality of the episcopal consecration and the collegiality of bishops. The Council granted all bishops fundamental equality in the Church. It manifests itself primarily in the right to participate in the General Council, the Synod of Bishops, and in the work of the Roman Curia. Their position in the local Church has also changed. The provisions of the new Code significantly added value to the legal position of the titular bishops, but did not make a radical change that would close the discussion on the role and tasks of titular bishops in the Church.

SŁOWA KLUCzOwE: biskupi tytularni; pozycja prawna Kościóła łacińskiego; ustawodawstwo; kolegialność; episkopat

KEYwORDs: titular bishops; legal position of the Latin Church; legislation; collegiality; episcopate

\section{NOTA O AUTORZE}

Ks. PROF. DR haB. JózeF Wroceński - kapłan Zgromadzenia Księży Sercanów, profesor nauk prawnych Wydziału Prawa Kanonicznego Uniwersytetu Kardynała Stefana Wyszyńskiego w Warszawie. W latach 1999-2005 prodziekan, a w latach 2005-2012 dziekan Wydziału; kierownik Katedry Ustroju Kościoła i Kanonicznych Form Życia Konsekrowanego. 